\title{
Neogenní a kvartérní sedimenty v oblasti Nového Hrádku (západní část NP Podyjí)
}

\author{
Neogene and Quaternary deposits in the closest surroundings of the Nový Hrádek \\ (the Podyjí National Park)
}

\author{
Slavomír Nehyba ${ }^{1} \rightrightarrows$, Karel Kirchner $^{2}$, František Kuda ${ }^{2}$ \\ ' Ústav geologických věd PřF MU, Kotlářská 2, 61137 Brno \\ 2 Ústav geoniky AVČR, v.v.i., pobočka Brno, Drobného 28, 60200 Brno
}

Key words:

Lower Miocene; Quaternary; provenance analysis; depositional environment

凸 slavek@sci.muni.cz

Editor:

Pavla Tomanová Petrová

\begin{abstract}
Neogene deposits of the Carpathian Foredeep were newly recognized in the sedimentary succession within the outcrop close to Nový Hradek site in the area of the Podyji National Park covered by extensive Quaternary deposits. These deposits are preserved as erosional relics within a bowl shaped depression on the top of the crystalline basement. Facies analysis shows that the recognised Neogene beds represent fluvial deposits. Two facies associations were identified within the Quaternary deposits. Although both of them are interpreted as colluvial deposits, they were formed by a series of gravity flows with highly varied water content. The provenance analysis (pebble petrography, association of heavy minerals, zircon study) confirmed, that the source area of both Neogene and Quaternary deposits was located in the adjacent geological units with strong dominance of Moravian Unit. Relatively high mineral maturity of the studied deposits points to extended blanket of intensely weathered crystalline basement, which underwent erosion and redeposition. Higher content of quartz clasts within the Neogene deposits reveals different mode of transport and possible redeposition from older sediments. Studied Neogene deposits are preliminary related to quartzose gravel and sands known from the close surrounding of the nearby Lukov village. Comparison of Neogene and Quaternary deposits in the surroundings of Nový Hrádek and occurrences of similar sediments within the National Park in Austria (e.g. surroundings of Merkersdorf) might provide a further data about the poorly known history of the area during Neogene.
\end{abstract}

Úvod

Geologické výzkumy v oblasti Národního parku (NP) Podyjí byly zaměřeny převážně na mapovací práce a studium krystalinických hornin vycházejíc z předpokladu, že na strmých svazích údolí Dyje a dolních úseků jejich přítoků mladší pokryvy a mocnější zvětraliny nevznikly nebo byly již odneseny (Jenček et al. 1984). Přesto existuje řada geologických i geomorfologických prací popisujících převážně kvartérní sedimenty nejrůznější geneze z území parku (Brzák 1998; Havlíček 1990, 2003; Kirchner et al. 1996, 1997, 2000; Šušolová 2005 atd.). V blízkém v. okolí národního parku se kvartérními štěrkovitými akumulacemi zabýval Karásek (1985), vazbu k dané oblasti má i práce Roštínského et al. (2016). Studium reliktů fluviálních a svahových sedimentů nabízí možnost poznání vývoje kaňonovitého údolí Dyje v kenozoiku a jeho zařazení do kontextu vývoje jv. okraje Českého masivu. Zachované sedimenty jsou spojovány s depresemi $\mathrm{v}$ poměrně hluboce zvětralém reliéfu, který byl rozbrázděn řadou úzkých koryt. 


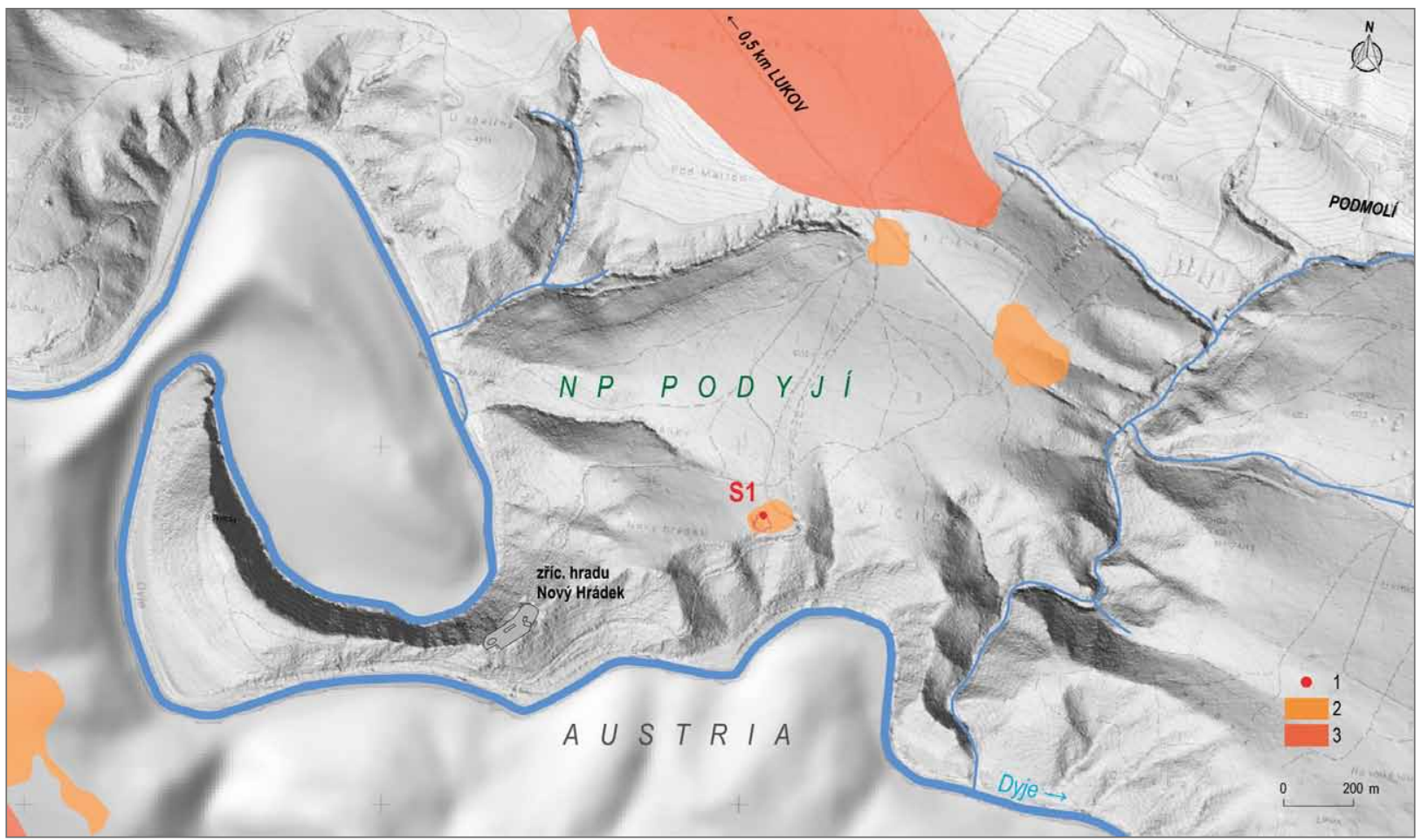

Obr. 1: Lokalizace zájmového území v digitální mapě reliéfu s rozsahem neogenních sedimentů dle Roetzela et al. (2005). 1 - sonda S1; 2 - křemenné štěrky, jemnozrnné písky; 3 - kaolinizované písky a pískovce, štěrky.

Fig. 1: Location of the studied area in digital elevation model. The areal extent of the Neogene deposits according to Roetzel et al. (2005). 1 - dug hole S1; 2 - quartzose gravels, fine-grained sands; 3 - kaolinised sands and sandstones, gravels.

Zneogenních sedimentů jsou zmiňovány především výskyty křemenných štěrků přecházejících do jemnozrnných, většinou kaolinických křemenných pískủ (Čtyroký et al. 1990) vystupující především v okolí Lukova. Dle Mátla (1995) byly na plošinách v. a jv. od Podmolí zjištěny vrtným průzkumem erozní deprese, vyplněné neogenními (ottnang-eggenburg) sedimenty. Detailněji byly hodnoceny pouze štěrky na lokalitě Kraví hora u Konic (Batík et al. 1982; Kirchner et al. 1999; Nehyba 2003). Tyto křemenné štěrky v nejvýchodnější části parku jsou Roetzelem et al. (2005) stratigraficky řazeny k ottnangu.

$\mathrm{V}$ rámci národního parku se přibližně $110-135 \mathrm{~m}$ nad údolím Dyje ostrůvkovitě nachází lokality písčitých štěrků stratigraficky řazených do pliocénu a jsou spojovány s tokem Dyje (Roetzel et al. 2005). Jednou z těchto lokalit je i stará opuštěná těžebna asi $800 \mathrm{~m}$ vsv. od zříceniny Nového Hrádku. Nachází se v ploché sníženině, mírně se sklánějící k JV k údolí Dyje. Štěrkovna je protažena ve směru SZ-JV cca v délce $70 \mathrm{~m}$. Její dno je stupňovité $s$ náletovou stromovou a keřovou vegetací. Nepodařilo se zjistit, kdy skončila těžba, ani její účel. Je však pravděpodobné, že štěrky a písky sloužily k zpevňování účelových komunikací v hraničním pásmu. Těžebna je dnes prakticky zasucena a sedimenty jsou díky tomu špatně př́istupné. Zasucená stěna štěrkovny (výška 4,5-5,0 m) je exponována $\mathrm{k} \mathrm{JZ}$ a její horní hrana leží v nadmořské výšce $394 \mathrm{~m}$. Stáří štěrkovito-písčitých sedimentů je udáváno jako ottnang-eggenburg (Batík red. 1990) nebo ottnang (Batík 1992). Ale již na rakouské geologické mapě $1: 50000$, list č. 9 Retz, jsou tyto sedimenty řazeny do svrchního pliocénu (Roetzel et al. 1999). Geologická mapa (Roetzel et al. 2004) přináší výrazně plošně revidovaný tvar sedimentárního pokryvu a řadí ho do pliocénu. Na základě souhlasu Správy NP Podyjí jsme se pokusili získat další informace o charakteru sedimentů odkrytých ve stěně štěrkovny s využitím kombinací dat získaných z ručně provedeného výkopu a elektrické odporové tomografie (ERT). Výsledky tohoto průzkumu a hodnocení odebraných vzorkủ jsou prezentovány v následujícím textu. Lokalizace terénních prací jsou znázorněny na obrázku 1.

\section{Metodika}

Odkrytá část stěny byla litologicky popsána a byla provedena faciální analýza dle Tuckera (1988); Walkera a Jamese (1992) a Nemece (2005). Odebrané vzorky sedimentů byly vyhodnoceny metodami granulometrické analýzy, petrografické analýzy zrnitostní frakce nad $4 \mathrm{~mm}$ a byl posouzen tvar a zaoblení klastů zrnitostní frakce nad $4 \mathrm{~mm}$ (dle Powerse 1982; Krumbein, Sloss 1951). V zrnitostní frakci $0,063-0,125 \mathrm{~mm}$ byla provedena analýza průsvitných těžkých minerálů a hodnocení vnitřní i vnější morfologie zirkonů. Zrnitostní analýza byla uskutečněna kombinací metody sítování za mokra na normovaných sítech (Retsch AS - 200) a laserové difrakce (CILAS 1064). K určení zrnitostních charakteristik (Mz, oI) byly využity vzorce dle Folka a Warda (1957). Hodnocení charakteristik tvaru a zaoblení proběhlo pod binokulárním mikroskopem, hodnocení těžkých minerálů a zirkonu pod polarizačním mikroskopem. Terminologie tvaru a zaoblení vychází z klasifikací Powerse (1953) a Zingga (1935). 


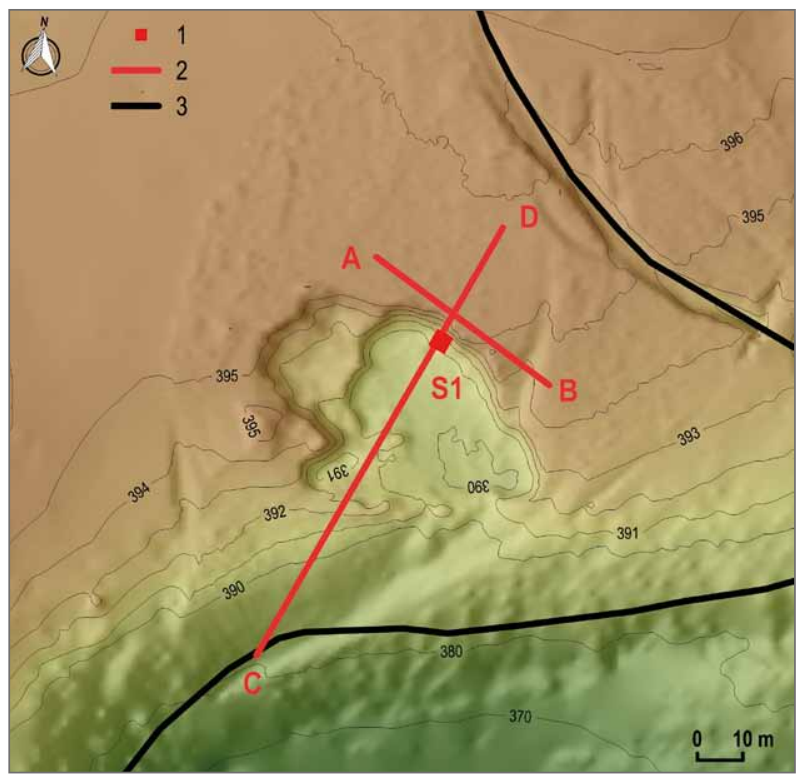

Obr. 2: Litologický profil provedeným odkryvem. 1 - sonda S1; 2 - profil ERT; 3 - cesta.

Fig. 2: Sedimentological log of the artificial outcrop. 1 - dug hole; 2 - profile ERT; 3 - road.

Naměřené ERT profily (pozice je znázorněna na obrázku 2) byly standardně zpracovány programem Res2DInv a graficky vizualizovány v programu Surfer do jednotné barevné stupnice. Výběr výsledné varianty modelu (iterace) byl proveden na základě statistické a vizuální shody naměřených hodnot zdánlivého měrného odporu (Rz) a vypočítaných modelových odporů (Rm).

\section{Výsledky \\ 1. Faciální analýza a elektrická odporová tomografie (ERT)}

Faciální analýza více než $5 \mathrm{~m}$ mocného profilu odkrytého výkopem umožnila vyčlenění 6 litofacií. Základní litologické charakteristiky vyčleněných litofacií jsou uvedeny v tabulce č. 1 a litologický profil na obrázku 3. Prostorové rozšíření litofacií i jejich geneze vedla k vyčlenění tří faciálních asociací, které mimo jiné odráží odlišná depoziční prostředí.
V nejnižší části profilu se nachází faciální asociace 1 (FA1), která je tvořena dvěma litofaciemi, tj. S3 a S2 a již velmi pravděpodobně pokrývá silně zvětralé krystalinické podloží. Kontakt s podložím nebyl zastižen. Valounová analýza v rámci litofacie S3 ukázala výraznou dominanci křemene (62,2 \%). Jako další byly zjištěny klasty křemen-živcového agregátu s proměnlivou kaolinizací živců (19,6 \%), kvarcitu (13,4\%), svoru $(3,7 \%)$ a grafitického kvarcitu (1,2 \%). Klasty křemene jsou převážně poloostrohranné (50\%). Relativně hojné jsou i polozaoblené $(28,3 \%)$ a zaoblené $(27,1 \%)$ křemeny. Naopak ostrohranné křemenné klasty jsou vcelku ojedinělé $(2,1 \%)$. Klasty křemene jsou většinou sférického tvaru (76,3\%). Výrazně méně hojné jsou křemeny čepelovitého $(11,8 \%)$, diskovitého $(9,8 \%)$ nebo sloupcovitého (2,0\%) tvaru. Podobně i zrna křemen-živcového agregátu jsou převážně poloostrohranná $(54,6 \%)$, méně polozaoblená $(36,4 \%)$ nebo ostrohranná $(9 \%)$. Zrna agregátu mají především sférický tvar (66,7\%), případně tvar diskovitý (25\%) nebo čepelovitý (8,9\%). Klasty kvarcitu jsou vyrovnaně polozaoblené (50\%) i poloostrohranné (50\%) a mají převážně diskovitý tvar (61,5\%). Méně četné jsou pak čepelovité (32,8\%) nebo sférické $(7,7 \%)$ kvarcity. Největší klast dosahoval velikosti téměř $10 \mathrm{~cm}$ (osa A), většinou však velikost valounů byla do $3 \mathrm{~cm}$. Nadložní litofacie S2 je tvořena proměnlivě zrnitými převážně jemnozrnnými písky, které jsou relativně dobře vy tříděné a vykazují mírně ukloněnou planární laminaci. Mocnost setů $10-20 \mathrm{~cm}$. Ukloněná tělesa přibližně deskovitého tvaru jsou sledovatelná na vzdálenost $50 \mathrm{~cm}$. Spodní hranice těles litofacie S3 je ostrá a víceméně planární. Svrchní vrstevní plocha tělesa litofacie S2 je erozní a nerovná. Střední velikost zrna Mz byla 3,7 $\Phi$ a hodnota vytřídění $\sigma \mathrm{I}$ pak 1,15. Asociace průsvitných těžkých minerálů byla zirkon $(25,6 \%)$ - staurolit $(23,8 \%)$ - disthen $(12,8 \%)$ a rutil (11,1 \%). Z ostatních těžkých minerálů byl výrazněji obsažen také turmalín (7,0 \%). Zastoupení ostatních minerálů (monazit, apatit, granát, andalusit, zoisit-epidot, korund a silimanit) bylo v prvních procentech. Hodnota ZTR indexu (Hubert 1962), který odráží zastoupení velmi stabilních těžkých minerálů, byla $43,7 \%$.

Tab. 1: Stručný popis vyčleněných facií.

Tab. 1: Descriptive summary of lithofacies of the studied deposits.

\begin{tabular}{|c|c|}
\hline Označení & Popis \\
\hline Gs & Rezavě hnědý velmi hrubozrnný písek s valouny až drobnozrnný štěrk, klasty do $2 \mathrm{~cm}$ v ose A, masivní, stopy po kořenech \\
\hline G1 & $\begin{array}{l}\text { Hrubozrnný štěrk, ostrohranné i poloostrohranné klasty do velikosti } 50 \mathrm{~cm} \text { (osa A). Nepravidelná orientace klastů, část protáhlých } \\
\text { klastů leží rovnoběžně s vrstevnatostí (osa A). Podpůrná struktura valounů až místy kostrovitá stavba, matrix tvořena špatně } \\
\text { vytříděným hrubozrnným pískem rezavě hnědým. Ostrá, velmi nepravidelná báze i svrchní vrstevní plocha. Velmi variabilní } \\
\text { mocnost těles, někdy jen izolované klasty. }\end{array}$ \\
\hline G2 & $\begin{array}{l}\text { Hnědavý či rezavě hnědý štěrk, podpůrná struktura písčité matrix místy až podpůrná struktura valouni̊n masivní. Valouny } \\
\text { do velikosti } 10 \mathrm{~cm} \text { (osa A), většinou do } 2 \mathrm{~cm} \text {, polozaoblené, poloostrohranné. Opakovaně amalgamované polohy. Plochy } \\
\text { amalgamace a báze zvýrazněné nabohacením hrubšími klasty, které leží částečně rovnoběžně s vrstevnatostí. Masivní stavba. } \\
\text { Nepravidelná báze i svrchní vrstevní plocha. } \mathrm{Mz}=-1,1 \text { až }-2,6 \phi ; \sigma \mathrm{I}=3,9-4,3 \phi\end{array}$ \\
\hline S1 & $\begin{array}{l}\text { Rezavě hnědý až rezavý hrubozrnný písek, špatně vytříděný. Ostrá báze i top, svrchní hranice tělesa erozní. Poloha čočkovitého } \\
\text { tvaru, erozní relikt, ukloněná planární laminace. }\end{array}$ \\
\hline S2 & $\begin{array}{l}\text { Světle zelenošedý, světle šedý, rezavě hnědý, místy rezavě, žlutavě či bělavě smouhovaný jemnozrnný, jemnozrnný až středozrnný, } \\
\text { středozrnný písek, relativně dobře vytříděný, slabě zřetelná mírně ukloněná planární laminace, ostrá báze i top, ukloněná tělesa. } \\
\mathrm{Mz}=3,7 \phi ; \sigma \mathrm{I}=1,15 \phi\end{array}$ \\
\hline S3 & $\begin{array}{l}\text { Rezavě hnědý, rezavý středozrnný až hrubozrnný písek, špatně vytříděný díky přítomnosti klastů až } 10 \mathrm{~cm} \text { především podél báze } \\
\text { polohy. Nerovná ostrá báze i top. Klasty krystalinika silně zvětralé, poloostrohranné i polozaoblené, orientované většinou osou } \\
\text { A rovnoběžně s bází tělesa. Klasty křemene zaoblené, osa A max. do } 3 \mathrm{~cm} \text {. Slabě zřetelná laminace }\end{array}$ \\
\hline
\end{tabular}




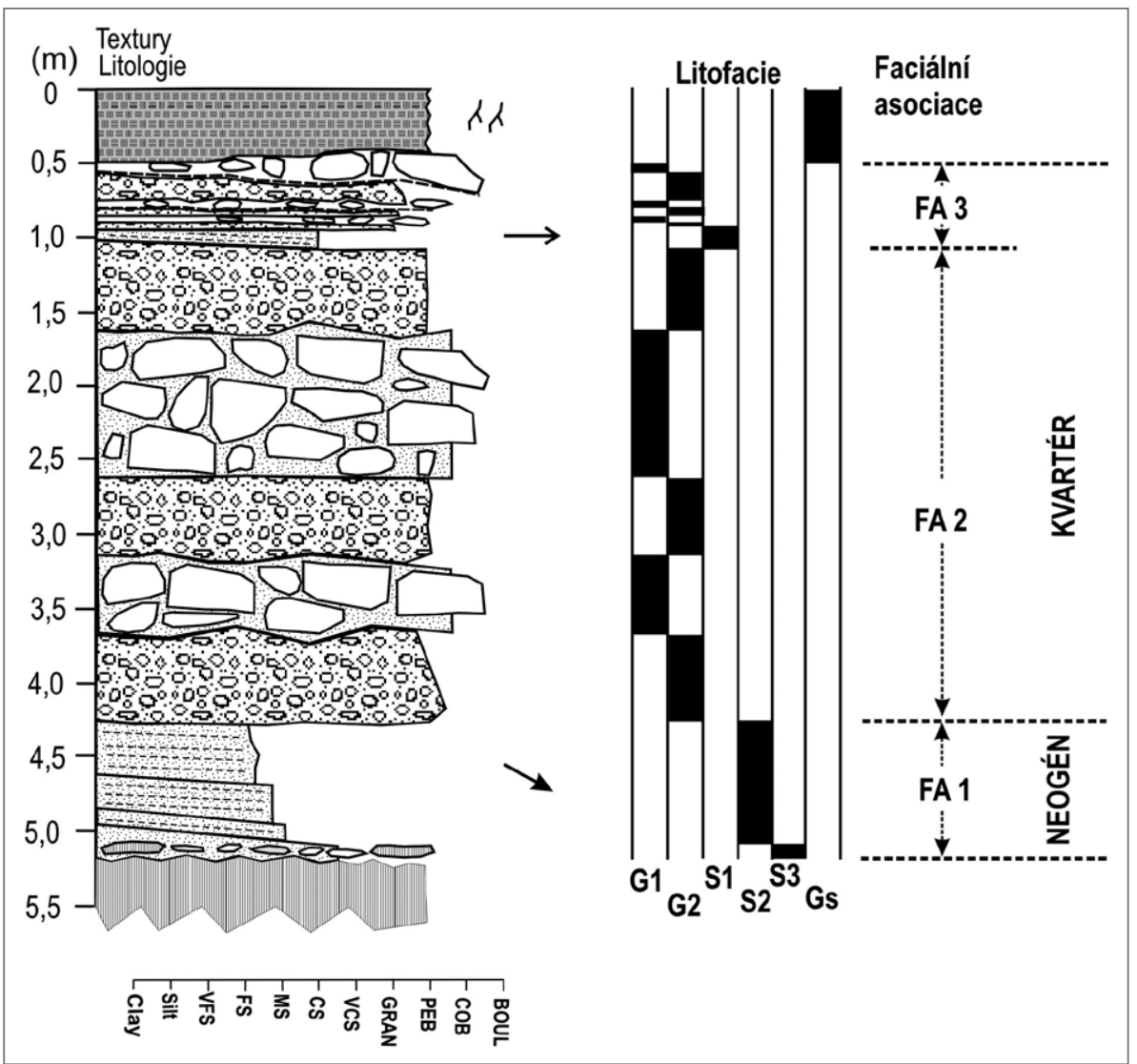

Obr. 3: Sedimentární profil výkopu.

Fig. 3. Sedimentary profile of dug hole.

V nadloží FA1 je nad ostrou erozní bázi uloženo přes $4 \mathrm{~m}$ mocné těleso FA2. FA2 je tvořena rytmicky se střídajícími polohami litofacií G1 a G2 a tvoří nejrozsáhlejší část odkryvu. Mocnost jednotlivých poloh litofacií G1 a G2 se pohybuje od $50 \mathrm{~cm}$ do přibližně $1 \mathrm{~m}$. Charakteristické jsou ostré, velmi nerovné hranice poloh jednotlivých litofacií, velmi špatné vytř́ídění a hojná prítomnost relativně velkých klastů krystalinika (až $50 \mathrm{~cm}$ v ose A). Valounová analýza klastů $\mathrm{z}$ facie G2 ukázala dominanci klastů křemene $(74,4 \%)$, následuje proměnlivě kaolinizovaný křemen-živcový agregát (17,8 \%), kvarcit (4,5\%), svor (1,9\%), fylit $(1,1 \%)$ a rula $(0,4 \%)$. Klasty křemene mají převážně čepelovitý (39,4\%) nebo sférický tvar (36,4\%). Diskovitý $(15,2 \%)$ a sloupcovitý tvar $(9,1 \%)$ jsou méně hojné. Klasty křemene jsou převážně zaoblené $(53,2 \%)$, polozaoblené (25\%), poloostrohranné $(15,6 \%)$ a jen podružně ostrohranné (6,3\%). Tvary klastů křemen-živcového agregátu tvarově relativně vyrovnané, když sférických bylo $30 \%$, diskovitých $25,0 \%$ a sloupcovitých i čepelovitých shodně $22,5 \%$. Klasty křemen-živcového agregátu jsou převážně polozaoblené $(52,5 \%)$ nebo poloostrohranné (40\%). Méně hojné jsou klasty ostrohranné (5\%) nebo zaoblené (2,5\%). Klasty kvarcitu vykazují především čepelovitý tvar (60\%), méně hojný je tvar diskovitý či sloupcovitý (vždy shodně 20 \%). Kvarcitové klasty jsou spíše polozaoblené $(60 \%)$ nebo ostrohranné (40\%). Valounová analýza klastů z facie G1 naznačuje dominancí klastů křemene $(74,8 \%)$ ve štěrkové frakci. Dále byl zjištěn proměnlivě kaolinizovaný křemen-živcový agregát (18,2\%), rula $(4,1 \%)$ a kvarcit $(2,9 \%)$. Klasty křemene byly převážně polozaoblené (41,1\%), méně časté byly klasty poloostrohranné $(32,6 \%)$, zaoblené $(22,1 \%)$ nebo ostrohranné (4,2\%). Klasty křemene mají především sférický tvar (59,2 \%). Ostatní tvary křemene, tj. čepelovitý (16,5\%), sloupcovitý $(12,6 \%)$ a diskovitý $(11,7 \%)$ mají prakticky shodné zastoupení. Klasty křemen-živcového agregátu jsou převážně poloostrohranné $(56,5 \%)$, i když polozaoblené tvary jsou také velmi hojné $(43,5 \%)$. Klasty tohoto agregátu mají převážně sférický tvar (44 \%). Ostatní tvary, tj. diskovitý (24\%), sloupcovitý (16\%) a čepelovitý (16\%) jsou méně hojné. Největší klasty tvořily kvarcity a ruly, jejichž velikost dosahovala až kolem $50 \mathrm{~cm}$. Klasty křemene jsou výrazně menší a dosahují maximálně $4 \mathrm{~cm}$. Klasty kvarcitu byly pouze angulární a diskovité. Střední velikost zrna $\mathrm{Mz}$ byla velmi proměnlivá od $-1,1$ do $-2,6 \Phi$ a hodnoty vytř́ídění oI byly velmi nízké tj. 3,9 až 4,3. Asociace průsvitných těžkých minerálů: zirkon $(17,2 \%)$, disthen (17,2 \%), staurolit $(13,9 \%)$ a turmalín $(13,3 \%)$. Z dalších minerálů byl relativně častější apatit $(8,6 \%)$, granát $(6,6 \%)$ a monazit $(5,3 \%)$. Ostatní minerály (amfibol, spinel, rutil, epidot-zoisit, silimanit a titanit) byly zastoupeny pouze prvními procenty. Zajímavá byla prítomnost nezlomených dlouze prismatických turmalínů a zčásti i protáhlých zrn disthenu. Hodnota ZTR indexu byla $34,5 \%$.

V nadloží FA2 je nad ostrou erozní bázi uloženo přibližně $0,5 \mathrm{~m}$ mocné těleso FA3, které představuje nejvíce variabilní část odkrytého sedimentárního profilu. Pro FA3 je typické střídání max. $20 \mathrm{~cm}$, ale většinou do $10 \mathrm{~cm}$, mocných těles facií S1, G1 a G2. Ve spodní části FA3 je uloženo čočkovité neprůběžné těleso litofacie $\mathrm{S} 1$. V jeho nadloží lze sledovat rytmické střídání relativně mocnějších těles sedimentů litofacie G2 a méně mocných těles litofacie G1, která mají místy až diskontinuální průběh. Sedimenty S1 ukazují na transport celkově $\mathrm{k} \mathrm{V}$.

Naměřené ERT profily (obr. $4 \mathrm{~A} \mathrm{a} \mathrm{B}$ ) byly orientovány jednak podél okraje stěny těžebny (profil A-B, orientace ZSZ-VJV), a jednak kolmo ke stěně těžebny směrem $\mathrm{k}$ údolí řeky (profil C-D, orientace JJZ-SSV).

\section{Interpretace}

V rámci profilů (obr. 3 a 4) lze sledovat velmi nepravidelné podloží krystalinika, které omezuje 


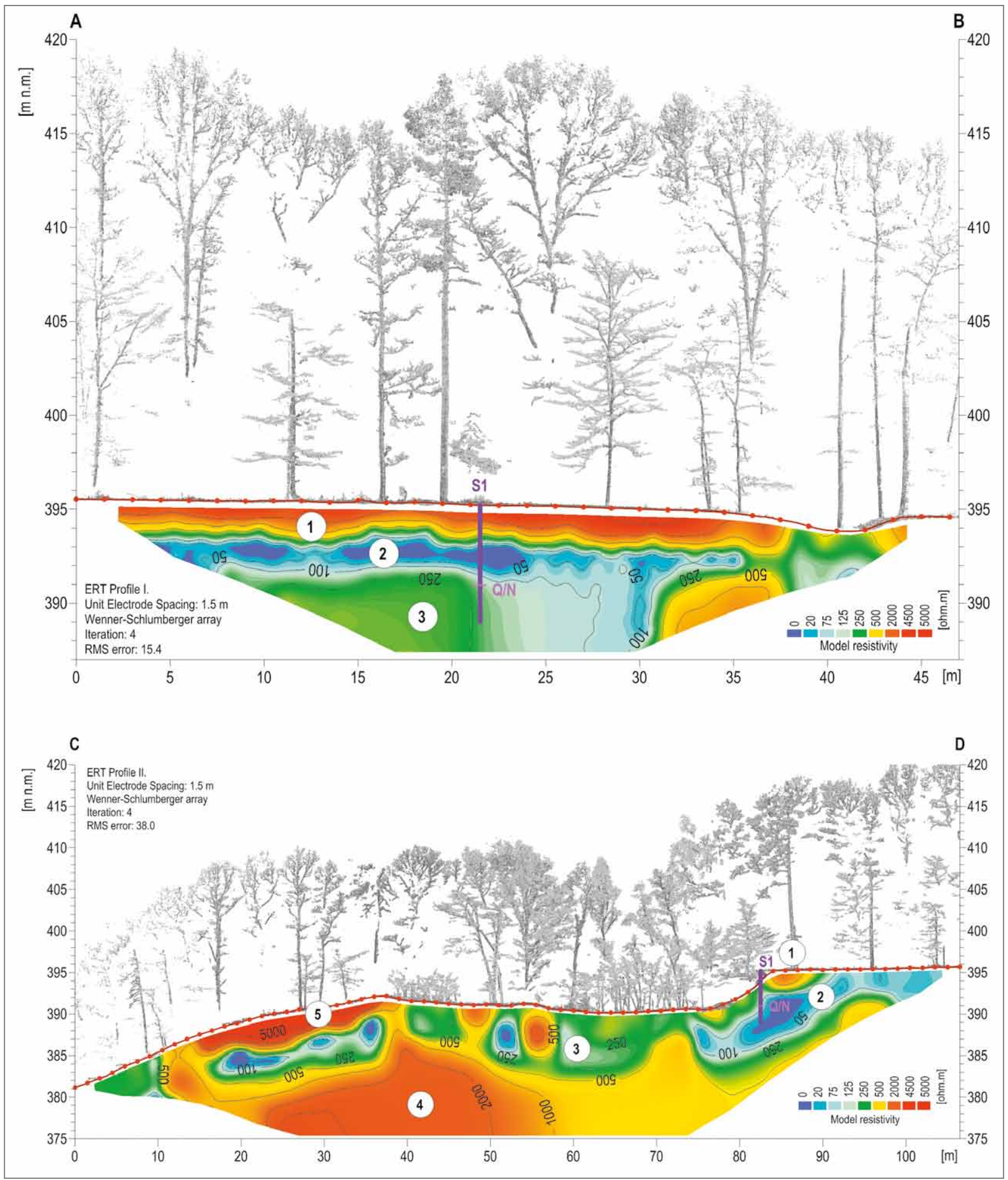

Obr. 4: ERT profily na zájmové lokalitě.

Fig. 4: ERT profiles on the locality.

a predisponuje výskyt sedimentů i samotnou těžebnu. Zachování neogenních písků je nejspíše reliktní a ostrůvkovité. Dále lze odlišit silně vrstevnaté sedimenty FA1 a tence vrstevnaté sedimenty FA2 a zejména FA3. $\mathrm{V}$ rámci profilu C-D lze sledovat ovlivnění sedimentárních těles také výrazným sklonem k řece Dyji. Nejvyšší partie profilu zde může tvořit i hrubozrnný odval těžebny, následně resedimentovaný $\mathrm{kJJZ}$.

Špatné vytřídění, př́itomnost silně zvětralých klastů krystalinických hornin, proměnlivé zaoblení klastů krystalinických hornin i křemene s výraznějším výskytem zaoblených valounů křemene, malá tvarová rozrůzněnost a hrubě planární až mírně ukloněné zvrstvení ukazují na trakční sedimentaci $\mathrm{z}$ vodního proudu se značnou energií proudění pro FA1. Facie S3 je interpretována jako sedimenty bazální části fluviálního valu, př́padně rríčního koryta (Bridge 1993; Miall 1996). Jednoznačná interpretace je znemožněna neznalostí tvaru tělesa facie S3. Lze spekulovat o sedimentaci v rámci říčního koryta, ale i o sedimentaci z přivalového/štítového proudu. 

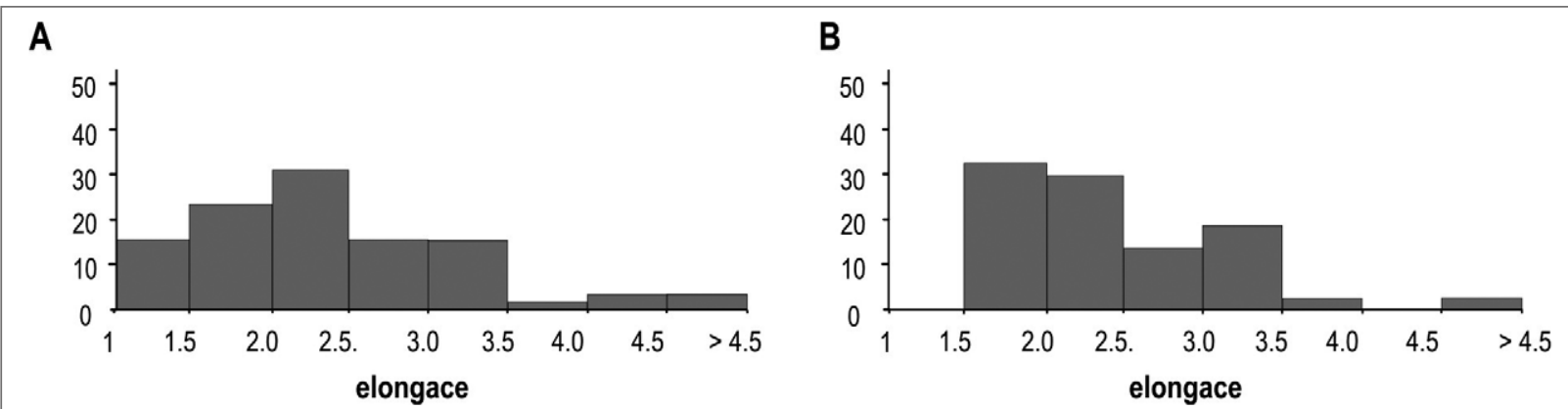

C

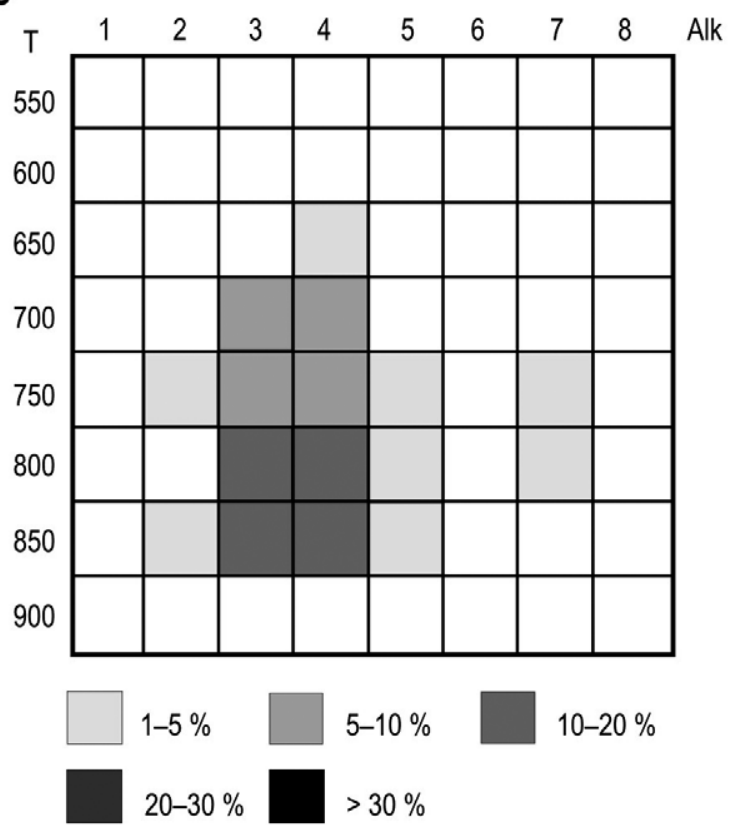

D

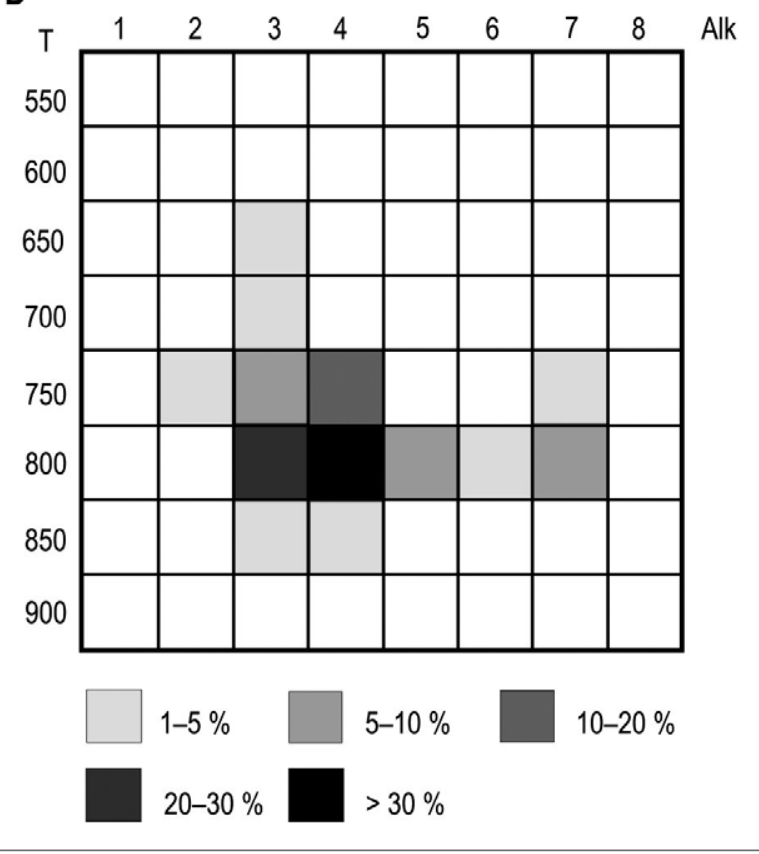

Obr. 5: Diagramy pro hodnocené zirkony. A - Histogram elongace zirkonů pro FA1, B) Histogram elongace zirkonů pro FA2, C) Typologie zirkonů pro FA1 v Pupinově diagramu (Pupin 1980), D) Typologie zirkonů pro FA2 v Pupinově diagramu (Pupin 1980). Fig. 5: Diagrams for studied zircons. A) Histogram of zircon elongation of FA1, B) Histogram of zircon elongation of FA2, C) Typology of zircons of FA1 in the Pupin diagram (Pupin 1980), D) Typology of zircons of FA2 in the Pupin diagram (Pupin 1980).

Zdrojem materiálu byly především intenzivně zvětralé krystalinické horniny moravika, které vystupují v nejbližším okolí lokality, a určitá část materiálu pochází ze starších sedimentů, které se mohly nacházet i v poněkud větší vzdálenosti než v nejbližším okolí. Křemen-živcový agregát však může pocházet také $\mathrm{z}$ hornin dyjského masivu. Relativně dobré vytř́ídění, ukloněné šikmé zvrstvení a malá mocnost sedimentárních těles litofacie S2 ukazují na trakční sedimentaci $\mathrm{z}$ vodního proudu s celkovým směrem transportu k JV. Sedimenty litofacie S2 jsou interpretovány jako sedimenty svrchních částí fluviálního valu. Faciální asociace odráží zdroj z intenzivně zvětralých metamorfovaných hornin a vcelku odpovídá asociaci těžkých minerálů popsaných pro spodnomiocenní sedimenty (eggenburg-ottnang) z. okraje karpatské předhlubně na Znojemsku (Batík et al. 1982; Čtyroký et al. 1990). Poměrně vysoká hodnota indexu ZTR ukazuje nejspíše na určitou roli redepozici ze starších sedimentů. Sedimenty litofacie FA1 jsou jako celek interpretovány jako neogenní sedimenty usazené z vodního proudu do ploché deprese protažené ve směru k JV.
$\mathrm{V}$ případě FA2 mocnost těles litofacií, masivní stavba, stř́íání podpůrné struktury matrix a podpůrné struktury valounů, výskyt kostrovité stavby, špatné vytř́ídění, relativně hojné ploše ležící protažené či ploché klasty a ploché ostré neerozní báze těles celkově vypovídají o sedimentaci z gravitačních proudů, které se lišily mechanismem transportu/podpůrného mechanismu částic. Facii G2 lze spojit se sedimentací z nekohezivních úlomkotoků („debris flow“). V rámci facie G1 lze předpokládat menší roli nekohezivní matrix během transportu a vyšší roli prrímého působení gravitace, tj. víceméně samostatný pohyb jednotlivých klastů („debris fall“) a př́padnou roli vody. Tyto rozdíly nejspíše odráží rozdílné klimatické podmínky panující během vzniku jednotlivých litofacií spojených s dostupností vody a jemnozrnného materiálu (matrix). Relativně velké mocnosti těles mohou poukazovat na relativní stabilitu podmínek či proximální či „hlavní “ ćásti proudů. Přítomnost dlouze prizmatických "nezlomených“ krystalů v rámci asociace těžkých minerálů potvrzuje transport na relativně malou vzdálenost. Zdrojem materiálu byly především okolní krystalinické 
horniny moravika, ale také starší neogenní sedimenty (nejspíše neogenní štěrky). Křemen-živcový agregát však může pocházet také $\mathrm{z}$ hornin dyjského masivu. Lze předpokládat výraznější roli redepozice ze starších neogenních sedimentů pro litofacii G2. Sedimenty FA2 lze celkově považovat za koluviální sedimenty.

Sedimenty FA3 odráží podmínky transportu a depozice $\mathrm{z}$ vodního proudu (S1), úlomkotoků (G2) a víceméně samostatného pohybu částic řízeného gravitací (G1). Výrazná př́tomnost sedimentace $\mathrm{z}$ vodního proudu je důležitým klimatickým signálem. Sedimenty FA3 jsou tedy kombinací sedimentace $\mathrm{z}$ gravitačních a vodních proudů. Malá mocnost těles (především facie G1) ve srovnání s FA2 může odrážet marginální či distální části gravitačních proudů či výrazně menší stabilitu podmínek. Zdrojová oblast se obecně neliší od FA2, pravděpodobná je vyšší role místního materiálu.

Nadložní litofacie Gs není dále hodnocena, protože byla velmi pravděpodobně značně ovlivněna antropogenní činností (těžba, doprava...).

\section{Studium zirkonů}

Vzhledem k dominanci zirkonu v asociaci průsvitných těžkých minerálů byla tomuto minerálu věnována detailnější pozornost, nebot' zirkon, jako jeden $\mathrm{z}$ nejstabilnějších těžkých minerálů, může poskytnout údaje o zdrojové hornině, charakteru transportu i redepozici. Kombinace metod posuzujících vnější i vnitřní charakteristiky zrn přináší informace o původu minerálu. Idiomorfní tvar zirkonů je považován za indikaci primárního zdroje a dokládá původ z magmatických či vulkanických hornin (Poldervaart 1950; Lihou, Mange-Rajetzky 1996). Zaoblená a polozaoblená zrna zirkonu mohou ukazovat na původ ze starších sedimentů - recyklace, z metamorfovaných hornin - primární zdroj nebo i magmatických hornin - sedimentární protolit či odraz kontaminace magmatu (Mader 1980; Winter 1981).

Ze sedimentů FA1 bylo celkem vyhodnoceno 110 zrn zirkonů. Zastoupení idiomorfních zirkonů představovalo $25,0 \%$, zatímco hypidiomorfní zirkony tvořily $35,3 \%$ a zirkony nepravidelně kulaté $36,2 \%$. Ze sedimentů FA2 bylo vyhodnoceno 94 zrn zirkonů. Zastoupení idiomorfních zirkonů představovalo $24,7 \%$, zatímco hypidiomorfní zirkony tvořily $28,9 \%$, zirkony nepravidelně kulaté $44,3 \%$ a kulaté zirkony $2,1 \%$.

Ve studovaném vzorku z FA1 nepatrně převažují čirá zrna (48,6\%) nad zrny zbarvenými (46,7 \%). Hnědé zirkony tvoří $2,8 \%$ a opakní $1,9 \%$. V hodnoceném vzorku z FA2 jsou výsledky hodnocení barvy zirkonů jen částečně odlišné. Převažují čiré zirkony (57,7\%), následovány zirkony zbarvenými (34,0 \%). Hnědé zirkony představují $7,2 \%$ a zirkony opakní $1,0 \%$.

Zastoupení zonálních zirkonů bylo v sedimentech FA3 9,1\% a v sedimentech FA2 12,8\%. Zirkony se staršími jádry tvoří $2,7 \%$ populace zirkonů ze sedimentů FA1 a 1,1\% ze sedimentů FA2. Zirkony s inkluzemi představovaly $95,5 \%$ studovaných zrn v sedimentech FA1 a $90,4 \%$ v sedimentech FA2.
Elongace zirkonů (poměr nejdelší osy/délky a nejkratší osy/šířky krystalů) může být využita k bližšímu určení zdroje zirkonů (Poldervaart 1950; Zimmerle 1979; Winter 1981) a poskytuje informace také o krystalizační teplotě (Pupin 1980). Průměrná hodnota elongace zirkonů z neogenních sedimentů FA1 byla 2,5. Zirkony s elongací vyšší než hodnota 2,0 převažují, když tvoří 60,7\%. Zirkony s elongací nad 3 reprezentují $19,7 \%$ a zirkony s elongací nad 4 7,2\%. Takové zirkony jsou spojovány s magmatickým/vulkanickým původem (Zimmerle 1979) a jen omezeným transportem. Maximální hodnota elongace byla 7,8. Hodnoty elongace pro zirkony z kvarterních sedimentů FA2 byly částečně odlišné. Průměrná hodnota elongace byla 2,5 a maximální 5,5 . Zirkony s elongací nad 2 predstavovaly $77,4 \%$, zirkony s elongací nad $323,2 \%$ a s elongací nad 4 pouze 2,3\% populace zrn. Rozložení elongace je ukázáno na obrázku $5 \mathrm{~A}$ a $\mathrm{B}$.

Zirkony dále vykazují srůsty a jsou často rozpukané. Hodnocení rozpukání zirkonu z FA1 ukazuje, že nerozpukané zirkony mírně převažují (54\%) nad zirkony puklými. Dále 41,6\% zrn vykazuje pukliny přibližně kolmé k nejdelší ose A, kdežto jen omezeně $(4,4 \%)$ kolmé k nejkratší ose C. Velmi podobná je situace u zirkonů z FA2, kde 53,2\% zirkonů je nerozpukaných, $41,5 \%$ je puklých kolmo k ose A a pouze 5,3\% kolmo k ose C. Drobné trhliny a praskliny vykazuje $86,4 \%$ zirkonů z FAla $95,7 \%$ zirkonů z FA 2.

Také typologie zirkonu může poskytovat údaje o bližších podmínkách krystalizace, tedy o mateřském magmatu. Rozdílná typologie zirkonů rozdílných magmatických rezervoárů byla ověřena a data využita k provenienčním studiím (Pupin 1980, 1985; Finger, Haunschmid 1988, etc.). V rámci zirkonů z FA1 byly nejvíce zastoupeny typologické subtypy S18 (12,6\%), S22 (12,6\%), S17 (11,0\%), S23 (10,1 \%), S12 (9,5\%) a S13 (9,5\%). Další subtypy S3, S7, S8, S11, S14, S19, S21, S24, P3 a P4 byly zastoupeny méně. Pro zirkony z FA2 byla zjištěna dominance subtypu S18 (30,8 \%), S17 (24,8 \%), S13 (12,8\%) a S12 (8,8 \%). Ostatní subtypy S2, S7, S11, S19, S20, S22, S23, P3 a P4 mají menší zastoupení. Rozložení typů zirkonů je znázorněno na obrázku $4 \mathrm{C}$ a D.

\section{Interpretace}

Srovnání typologie ukazuje celkově na společný zdroj pro sedimenty FA1 a FA2. Spektrum zirkonů je poměrně široké (lze částečně uvažovat o primárním zdroji především $z$ aluminických granitoidů) a především pro neogenní sedimenty je provenience relativně široká. Relativně vyšší zastoupení protáhlých zirkonů ukazuje na roli vulkanických hornin ve zdrojové oblasti. Pro sedimenty FA2 je zdroj zirkonů více uniformní. Lze doložit určitou podobnost v zastoupení hlavních subtypů zirkonů s hodnotami zjištěnými v rámci žerotického souvrství (Nehyba et al. 2019) a předpokládat dominantní původ zirkonů $\mathrm{z}$ hornin moravika.

\section{Diskuze a závěr}

Geofyzikální studium potvrdilo velmi nepravidelný povrch krystalinika a akumulace sedimentů vázané na mísovité deprese krystalinického podloží. 
Valounová analýza spolu s analýzou těžkých minerálů ukázaly na zdroj z intenzivněji zvětralého krystalinika $\mathrm{v}$ případě sedimentů $\mathrm{FA} 1$ (neogén), i v případě nadložních kvartérních (pliocenních?) sedimentů (FA2 a FA3). Výraznější zastoupení křemene a jeho vyšší zaoblení zjištěné pro neogenní sedimenty ukazuje na redepozici části materiálu ze starších sedimentů, jiný způsob transportu a depozičního prostředí ve srovnání s nadložními sedimenty kvartérními. Neogenní sedimenty lze spojit s existencí vodního toku, kdežto kvartérní sedimenty mají charakter depozice $\mathrm{z}$ gravitačních proudů $\mathrm{v}$ rámci koluvia. Minerální zralost sedimentů spolu s vysokým zastoupením stabilních těžkých minerálů poukazují na existenci rozsáhlého pokryvu zvětralin vzniklých $\mathrm{v}$ rámci intenzivních zvětrávacích pochodů. Malé zachování těchto zvětralin lze spojit s jejich erozí a redepozicí. Podobně můžeme oprávněně předpokládat rozsáhlé pokryvy neogenních sedimentů především křemenných štěrků (viz vysoké zastoupení zaoblených valounů křemene v kvartérních sedimentech) v zájmové oblasti, které již nejsou zachovány. Lze spekulovat o spojení zjištěných neogenních sedimentů $s$ výskyty křemenných štěrků a písků na SZ a JV od Lukova.

Polymiktní charakter zastižených štěrků je zřetelně odlišuje od neogenních štěrků známých z okolí Kraví hory v nejvýchodnější části NP Podyjí (Nehyba 2003). Popsané sedimenty vypovídají o relativně dynamickém reliéfu v zájmové oblasti. Jako zajímavé se jeví srovnání těchto sedimentu s lokalitami v rámci NP Thayatal v Rakousku (např. v okolí Merkersdorfu).

\section{Poděkování}

Za posouzení príspěvku a pripomínky jsme povinováni díkem recenzentům Janu Vítovi a Martinu Hanáčkovi. Terénní práce proběhly s laskavým souhlasem Správy NP Podyjí ve Znojmè.

\section{Literatura}

Batík, P., Čtyroký, P., Klečák, J., Gabriel, M., Štych, J., Střída, M., Šalanský, K., Zeman, A., Holásek, O. (1982). Vysvětlivky k základní geologické mapě ČSSR $1: 25$ 000, list 34-131, Šatov. 72 s., Ústřední ústav geologický. Praha.

Batík, P. red. (1990). Geologická mapa ČR. List 33-24 Hnanice. Měřítko 1 : 50 000. - Ústřední ústav geologický. Praha.

Batík, P. (1992). Geologická mapa Národního parku Podyjí. Český geologický ústav, Praha.

Batík, P., Barnet, I., Čtyroký, P., Čurda, J., Havlíček, P., Hazdrová, M., Líbalová, J., Šalanský, K. (1995). Vysvětlivky k základní geologické mapě ČR $1: 25$ 000, list 33-242, Hnanice. 27 s. Ústř̌ední ústav geologický. Praha.

Brzák, M. (1998). Př́ispěvek k vývoji údolí Dyje mezi Vranovem a Znojmem na základě morfometrické analýzy a výzkumu fluviálních sedimentů. - Geografie, Sborník ČGS, 103, 1, 31-45, Praha. 
Bridge, J. S. (1993). Description and interpretation of fluvial deposits: a critical perspective. - Sedimentology, 40, 801-810, Oxford. https://doi.org/10.1111/j.1365-3091.1993.tb01361.x

Finger, F., Haunschmid, B. (1988). Die mikroskopische Untersuchungen der akzessorischen Zirkone als Methode zur Klärung der Intrusionsfolge in Granitgebieten - eine Studie im nordöstlichen oberösterreichischen Moldanubikum. - Jahrbuch der Geologischen Bundesanstalt, 131/2, 255-266, Wien.

Folk, R. L., Ward, W. (1957). Brazos River bar: a study in the significance of grain-size parameters. - Journal of Sedimentary Petrology, 27, 3-26. Tulsa. https://doi.org/10.1306/74D70646-2B21-11D7-8648000102C1865D

Čtyroký, P., Batík, P., Gabriel, M., Šalanský, K., Holásek, O., Klečák, J., Mátl, V., Líbalová, J., Stř́ida, M., Matějovská, O., Štych, J., Zeman, A. (1990). Vysvětlivky k základní geologické mapě ČSSR $1: 25$ 000, list 34-113, Znojmo. - 79 s. Ústřední ústav geologický. Praha.

Jenček, V., Havlíček, P., Dornič, J., Šalanský, K., Hazdrová, M. Střída, M., Líbalová, J., Dudek, A. (1984). Vysvětlivky k základní geologické mapě ČSSR $1: 25$ 000, list 33-223, Vranov. - 60 s. Ústřední ústav geologický. Praha.

Havlíček, P. (1990). Kvartérně geologický výzkum území na listu 33-224 Kravsko. - Zprávy o geologických výzkumech v r. $1989,67$.

Havlíček, P. (2003). NP Podyjí: revizní kvartérně-geologický výzkum a mapování v letech 2001 a 2002. - Zprávy o geologických výzkumech v roce 2002, 71-73.

Hubert, J. F. (1962). A zircon-tourmaline-rutile maturity index and the interdependence of the composition of heavy mineral assemblages with the gross composition and texture of sandstones. - Journal of Sedimentary Petrology, 32, 440-450.

Karásek, J. (1985). Geomorfologická charakteristika reliéfu jižní části Znojemska. - Sborník Československé geografické společnosti 90, 3, 177-189. Academia Praha.

Kirchner, K., Ivan, A., Andrejkovič, T. (1997). Geomorfologický výzkum Národního parku Podyjí a jeho severního okolí. - Geologické výzkumy na Moravě a ve Slezsku v r. 1996, 10-12.

Kirchner, K., Ivan, A., Brzák, M. (1996). K rozšíření kvartérních fluviálních sedimentů v údolí Dyje v NP Podyjí. - Geologické výzkumy na Moravě a ve Slezsku v r. 1995, 21-23.

Kirchner K., Ivan, A., Hofírková, S., Petrová, A., Andrejkovič, T. (2000). Antropogenní transformace reliéfu východní části Národního parku Podyjí. - Geologické výzkumy na Moravě a ve Slezsku v r. 1999, 31-33.

Kirchner, K., Ivan, A., Hubatka, F., Nehyba, S. (1999). Reliéf východního okraje Národního parku Podyjí. - Geologické výzkumy na Moravě a ve Slezsku v r. 1998, 21-23.

Krumbein, W. C., Sloss L. L. (1955). Stratigraphy and sedimentation. - W. H. Freeman and co., 660 pp.

Lihou, J. C., Mange-Rajetzky, M. A. (1996). Provenance of the Sardona Flysch, eastern Swiss Alps: example of high-resolution heavy mineral analysis applied to an ultrastable assemblage. - Sedimentary Geology, 105, 141-157. https://doi.org/10.1016/00370738(95)00147-6

Mader, D. (1980). Weitergewachsene Zirkone im Bundsandstein der Westeifel. - Der Aufschluss, 31, 163-170.

Miall, A.D. (1996). The Geology of Fluvial Deposits. - Springer Verlag, 582 pp., Berlin.

Nehyba, S. (2003). Štěrky na lokalitě Kraví hora u Konic. - Thayensia, 3, 3-12.

Nehyba, S., Otava, J., Tomanová Petrová, P., Gazdová, A. (2019). The foreland state at the onset of the flexurally induced transgression - data from provenance analysis at the peripheral Carpathian Foredeep (Czech Republic). - Geologica Carpathica, 2, 241-260. https://doi.org/10.2478/geoca-2019-0014

Nemec, W. (2005). Principles of lithostratigraphic logging and facies analyses. - Institutt for geovitenskap, Universitetet i Bergen, $1-28$.

Poldervaart, A. (1950). Statistical studies of zircon as a criterion in granitization. - Nature, 165, 574-575. https://doi.or$\mathrm{g} / 10.1038 / 165574 \mathrm{~b} 0$

Powers, M. C. (1953). A new roundness scale for sedimentary particles. - Journal of Sedimentary Petrology, 23, 1, 118. Tulsa. https://doi.org/10.1306/D4269567-2B26-11D7-8648000102C1865D

Powers, M. C. (1982). Comparison chart for estimating roundness and sphericity. - AGI Data Sheet 18.

Pupin, J. P. (1980). Zircon and Granite Petrology. - Contributions to Mineralogy and Petrology, 73, 207-220.

Pupin, J. P. (1985). Magmatic zoning of hercynian granitoids in France based on zircon typology. - Schweizerische Mineralogische und Petrographische Mitteilungen, 65, 29-56. https://doi.org/10.1007/BF00381441

Roetzel, R., Fuchs, G., Batík, P., Čtyroký, P. (1999). Geologische Karte der Republik österreich. 1 : 50 000. 9 Retz. - Geologische Bundesanstalt. Wien.

Roetzel, R., Fuchs, G., Batík, P., Čtyroký, P. (2004). Geologische Karte der Nationaparks Thayatal and Podyjí. 1 : 25 000. - Geologische Bundesanstalt. Wien.

Roetzel, R., Fuchs, G., Havlíček, P., Übl, Ch., Wrbka, T. (2005). Geologie im Fluss. Erläuterungen zur Geologischen Karte der Nationalparks Thayatal un Podyjí. - Geologische Bundesanstalt. Wien. 1-92.

Roštínský, P., Šmerda, J., Nováková, E. (2016). Geomorfologické a petrografické aspekty fluviálních sedimentů v oblasti dolní Rokytné. - Thayensia (Znojmo) 2016, 13, 15-58.

Šušolová, J. (2005). Spraše na území Národního parku Podyjí. - Acta musei moraviae, scientiae geologicae, 155-169.

Tucker, M. ed. (1988). Techniques in Sedimentology. - Blackwell Science, 1,394.

Walker, R. G., James, N. P. (1992). Facies Models. Response to sea level changes. - Geological Association of Canada, 1-380, Toronto.

Winter, J. (1981). Exakte tephro-stratigraphische Korrelation mit morphologisch differenzierten Zironpopulationen (Grenzbereich Unter/Mitteldevon, Eifel-Ardennen). - Neues Jahrbuch für Geologie und Paläontologie, Abhandlungen, 162, 97-136.

Zimmerle, W. (1979). Accessory zircon from rhyolite, Yellowstone National Park (Wyoming, U.S.A.). - Zeitschrift der deutschen Geologischen Gesellschaft, 130, 361-369.

Zingg, T. (1935). Beiträge zur Schotteranalyse. - Schweizerische Mineralogische und Petrographische Mitteilungen, 15, 39-140. 